\title{
English Grammar On 2013 Curriculum: The Development of Game Based Learning Multimedia
}

\author{
Budi Setiawan, Asrowi \\ Doctoral Program of Education, Teacher Training and Education Faculty, Universitas Sebelas Maret, Indonesia
}

\begin{abstract}
This Research is aimed to find out the effectiveness of game based learning multimedia in order to gain student learning outcomes on English subject with the topic of grammar in the classroom. The research development of multimedia game based learning using the procedure of Raiser and Demsey consisting of 5 stages namely: 1) Analysis which covers needs and theoretical analysis, 2) Design which includes Core and basic competence's identification, material's selection and submission, flowchart and story board arrangement, 3) Develop that contains production, media and material's experts validation and students' responses and product's trial after the revision done. 4) Implement that covers the final product's application towards the experiment class, 5) Evaluate becoming the last stage of all by having a test for both classes which are control and experiment class to see whether is there any differences between the class applying the multimedia game based learning and not. The trial of product development tested had passed several processes covering; the review from media's expert which includes software changes and visual communication, the review from content's expert covers material and instructional design, students' responses towards products' usage and attractiveness, small group and big group test trial. The result showed that the students at the control class taught by conventional way as in speech has less motivation and lower score compared with the experiment class applying interactive multimedia game based learning. There is an interaction between learning media and learning motivation those effects on students' learning achievement especially in English grammar. Thus, it can be said that the result of the development of multimedia game based learning is effective to improve students learning outcomes.
\end{abstract}

Keywords: Multimedia, game based learning, grammar, learning outcomes

\section{Introduction}

Curriculum change will have a rational impact on the adjustment and change of various standards existed in a curriculum which has been designed and defined including the competence standard, this change is specifically shown from Curriculum 2006 (KTSP) into Curriculum 2013 (K-13). There are both direct and indirect effects as a sustainable impact caused from a result of the policy. Based on its function, the purpose of teaching English includes: (1) Developing the ability to communicate in the language both spoken and written including listening, speaking, reading, and writing; (2) Arising awareness of the essence and importance of English as a foreign language to become the main media for learning; (3) Creating the comprehension about interrelationship between language and culture as well as expanding cultural horizons so that students have crosscultural insights and willingness to involve themselves in cultural diversity.

As well as in English subjects, based on the distribution of content that refers to syllabus, there are differences in the inclusion of grammar or grammar skills in English subjects for tenth graders of senior high school. In English, grammar has a particular pattern that varies according to the context of the time.
Consequently, it will cause difficulties for students especially when the learning process of the learner is not well-facilitated by the size of the portion from the teacher to deliver the basic concept of grammar through teacher-centered. On the other hand, curriculum 2013 makes students to be more active in all aspects with smaller portion of teachers to take control in the process of teaching and learning activities. As a result, a shortterm effect that can be seen directly is students' confusion and lack of understanding of the basic concept of sentence patterns in an English language. Moreover, it also offers major implications in the cognitive or academic achievement of these students.

The role of teachers in choosing and determining learning materials or teaching materials becomes very important in solving learners' problems especially in learning activities. As a hereditary culture for many educators nowadays, in this case the teacher in particular, still apply conventional methods or techniques in teaching and learning activities. Most of educators have weakness in utilizing teaching materials and learning media because of their lack of innovation.

Nowadays, in millennial generation era people are forced to be global citizen. It means that all aspects must be related to computerization spreaded out almost in all 
areas of human life. Even the world of education is also connected to the computer invasion or commonly called as digital world. Furthermore, this digital era have people be creative in developing learning materials using computers as a source of learning besides books. According to Simonson \& Thomson (1994: 147), Computer Assisted Learning is effective in improving student mastery in all levels of education, highly effective in improving student mastery at primary school level continuing at intermediate to tertiary level and also can save the time for learning.

Encouraged by Yusuf Hadi Miarso (2005: 45) that learning developed or assisted by computer was able to increase students' motivation and their absorption capacity of the subject matter. This is because computerassisted learning method is able to cultivate motivation for students to be more comprehensive with material presented, add realism to conduct work exercises, and be able to stimulate students in responding learning materials to improve thier learning achievement.

The use of media that is still conventional becomes a crucial factor which requires to be upgraded and not only relies on a medium which is a book. It needs innovation in presenting teaching materials in other interactive forms that are able to attract students' enthusiasm and activeness, one of them is through computer-based interactive learning.

Thornburry (2002: 1) states "Traditionally, grammar has been almost exclusively with analysis at the level of the sentence. Thus grammar is a description of the rules that govern a language's sentence are formed". Meanwhile, grammar is related to sentence levels and pictures of rules governing the formation of a sentence in the language. In this case, the focus is more on the sentence and how to shape it. Meanwhile, according to Ur (2009: 75), grammar in general is sometimes defined as the way words are put together to make correct sentences. This opinion has similarities previously expressed by Thornburry which relates to the rules on how the sentence is compiled completely. Another definition stated by Harmer (2006: 18), he explains that "communicative competence involves knowing how to use the grammar and vocabulary of the language to achieve communicative goals, and knowing how to do this in a socially appropriate way". Grammar is related to knowledge and skills: how to recognize grammar examples when it is spoken, how to identify it in writing, how to make them both in spoken and written form, how to understand its meaning based on the context, and produce meaningful sentences in its use.

Grammar is one of the language components besides pronunciation, spelling and vocabulary. It becomes very essential as a means of communication. Suyanto (2007: 43) reveals that grammar consists of patterns and rules of language that should be learned if we want to speak English properly. Richards (2008: 145) emphasizes that "structure is still important to be taught in teaching English," he furthermore says that "now teaching structure has controversial issues in teaching English, but in recent years, grammar teaching has regained its rightful place in language curriculum". Teaching grammar is still considered important especially in teaching and learning activities as a means of communication. Additionally, a language will be grateful if it has the right grammar.

Smaldino, Lowther, \& Russell (2007: 6) ever stated that media is plural form of medium, which is a means of communication. This term refers to anything that can bring information from source to receiver. While according to Sri Pudjiastuti (1999: 2) the media is a case that can distribute the message from sender to receiver so that it can stimulate the thoughts, feelings, attention, and interests of students in such a way that the learning process occurs. According to Hackbarth (1996: 229), multimedia is defined as a combined use of some media in conveying information in the form of text, graphics or animated graphics, movies, video and audio. Multimedia using computer-based includes hypermedia and hypertext. Hypermedia is a use of multimedia presentation format which includes text, silent graphics or animated graphics, movie and audio formats. Hypertext is a form of text, static diagram, images and tables that are displayed and arranged in a nonlinear way (sequence or line)

Roblyer (2003: 164) states multimedia or combination media is a medium consisting of still images, sounds, motion videos, animations and text that are combined in a product that aims to provide information. Rob Philip (1997: 8) states multimedia is a combination of text, image, sound, animation and video; some or all components are incorporated into a coherent program. As Munir (2008: 234) states that multimedia presentation can be interpreted as a technology that optimizes the role of the computer as media that display text, sound, graphics, video, animation in a view that is integrated and interactive.

Computers become the primary media for presentation of multimedia programs. Components in the computer are able to display a perfect combination of audio and visual integrative and slick in one program. Impressions of interaction created become very natural because of giving the opportunity by the users to be engaged in these activities. Games are an entertaining and interesting activity, tend to challenge, and also an activity in which learners can play and interact with each other. According to Wright et al (2006: 3), “competition against others is not essential ingredient for games, but challenge is". In choosing and describing the game, it is good to minimize competition, winners and losers, and maximize challenges, where everyone feels inspired and enthusiastic to start playing and doing their best. Generally, video games are any type of games played with computer devices and in the form of video display. 
Media used can be through computer, cell phone, or game console. Those insights are general concepts that reflect our general understanding of the term "digital game" which does not mention all the complex components in it. According to ProActive: Fostering teachers' creativity through Game-Based Learning (2009), here are some characteristics or features of goodquality video games, favored by the general public and interesting among others; Conflict, Goal and Rules, Short Feedback Cycles, Immersion and Engagement, Challenge, Adaptability, Replayability, Reward System, Competition. The digital games are conditioning players in an unlimited world to explore without intervention from instructors. In this point, video games is an ideal medium for promoting real learning and a learning-bydoing process that can transform learners to be leaders of themselves in their learning experience. Hence, digital games are able to provide a meaningful learning experience by stimulating the interaction that a professional finds in the realm of real-world, where they can directly face related problems.

Based on the research problems mentioned above, the purpose of this study is to find the needs of teachers and students about multimedia for learning English, find procedures development of multimedia learning on the subject matter of an English grammar and find the effectiveness of learning by utilizing multimedia learning on an an English grammar for tenth graders senior high school.

\section{Methods}

This research is classified as developmental research or usually called R\&D (Research and Development). Research and Development is a process or steps to develop a new product or refine an existing product. The meaning of the product in this context is not only the hardware but also the software. The research has been done in SMAN 3 Sragen. This research was conducted in English subjects in grade ten. The population of the research is all students Furthermore, this study held in second semester of academic year 2017/2018 by involving four different classes, which are product trial class, experimental class, experiment class and control class. Besides, the research development procedure consists of two stages: developing the model product and testing the quality and /or the effectiveness of the product (Sukardjo and Sari, 2009: 66). In developmental research, there is known one of the development models called ADDIE model.

The ADDIE model is an easy-to-use model in which the process used is systematic with a clear framework that produces effective, creative, and efficient products (Raiser and Demsey, 2007: 25). The ADDIE development model is a model of instructional design based on an effective and efficient system approach and an interactive process, for example: the evaluation of each phase can lead to the development of learning to the next phase. The final result of this phase is the initial product for the next phase. This model consists of 5 phases which are 1) Analysis, 2) Design, 3) Development, 4) Implementation, and 5) Evaluation.

\section{Result And Dlscussion}

Multimedia Game-Based Learning

The development of products used as multimedia learning has been through several stages including production, validation of media experts, material expert validation and product trial. Here is the final model of the multimedia.

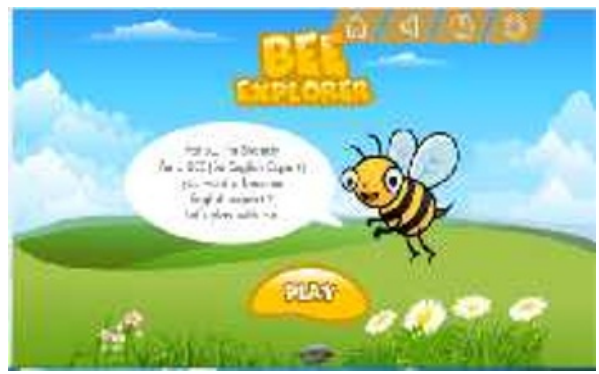

Figure 1. Games Opening

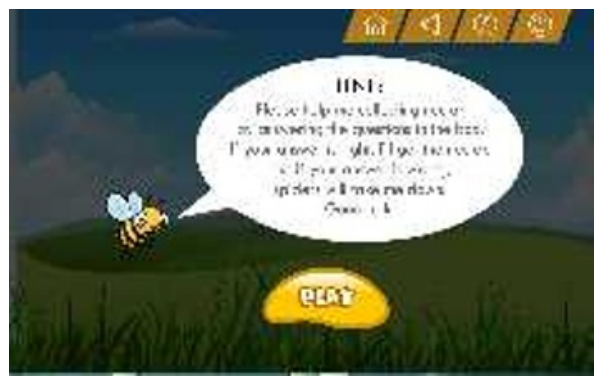

Figure 2. Games direction

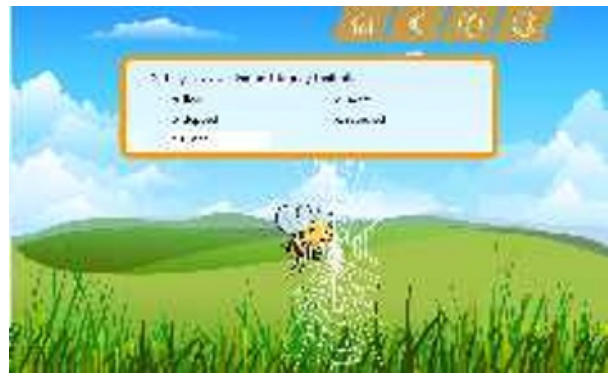

Figure 3. Wrong answer respond

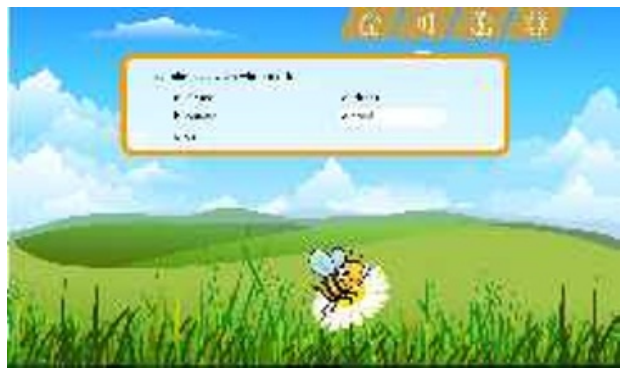

Figure 4. Correct answer respond

After the product has been declared feasible and tested, then the next step was to test the effectiveness of the product or called with the t-test by first performing the prerequisite test analysis. In test requirements 
analysis, it performed data analysis to test the hypothesis with t-test, then first test prerequisite analysis between classes which applied game based learning and classes which did not apply the same. The test requirements analysis is as follows.

\subsection{Normality test}

Normality test was conducted to determine the sample used in this study comes from the population with normal distribution or not. Kolmogrov smirnov test with $\alpha=0.050$ and assisted with SPSS 16 program. $\mathrm{H}_{\mathrm{o}}$ stated that the sample comes from a normally distributed population, if the significant value of the normality test is more than $\alpha(\operatorname{sig}>0,050)$ and $D_{\text {count }}<D_{\text {table }}$ then $H_{o}$ is accepted. Normality test results in this study were as follows.

Table 1. Pretest Normality Test of the Experiment Class and the Control Class

\begin{tabular}{llc} 
& Class & $\begin{array}{c}\text { Significant } \\
\text { Value }\end{array}$ \\
Score & Control & .085 \\
& Experiment & .060 \\
\hline
\end{tabular}

Based on table 1, it can be seen that the significant value of normality test was more than $\alpha(\operatorname{sig}>0,05)$, in experiment class $0,060>0,050$ and in control class $0,085>0,050$, so it can be concluded that cognitive value of pretest experiment class and the control class was normally distributed.

Table 2. Post test of Normality test in Experimental and Control Class

\begin{tabular}{llc} 
& Class & Significant \\
Value \\
Score & Control & .060 \\
& Experiment & .126 \\
\hline
\end{tabular}

Based on Table 2, it showed that the significant value of the normality test is more than $\alpha(\operatorname{sig}>0,050)$, in the experimental class $0.126>0.050$ and the control class normality test $0.60>0.050$, so it can be concluded that the cognitive value of pretest experimental class and the control class is also normally distributed.

\subsection{Homogeneity Test}

Homogeneity test was conducted to find out whether the data variance obtained between the tested groups was different or not. The method used was Levene's test with $\alpha=0.050 . H_{0}$ stated that each group did not have the same variance. The decision of this test was that if the sig value of the homogeneity test is higher than $\alpha$ (sig $>$ 0.050) then $\mathrm{H}_{\mathrm{o}}$ was accepted, and it means homogeneous. The homogeneity test results in this study were as follows.

Table 3. Pretest Homogeneity Test of Experiment Class and Control Class

\begin{tabular}{cllc}
\hline Levene & & \multicolumn{2}{c}{ Significant } \\
Statistics & df1 & df2 & Value \\
Score & 1 & 62 & .139 \\
& & & \\
\hline
\end{tabular}

Based on Table 3, it is known that Levene's Test significance value is 0.139 . The value is higher than
0.05 , so it can be concluded that the pretest cognitive values between the experimental and control classes has a homogeneous variance.

Table 4. Posttest Homepage Test of Experiment and Class Control

\begin{tabular}{cllc} 
Levene & & \multicolumn{2}{c}{ Significant } \\
Statistics & df1 & df2 & Value \\
Score & 1 & 62 & .576
\end{tabular}

Based on Table 4, it is known that Levene's Test significance value is 0.576 . The value is higher than 0.05 , so it can be concluded that the posttest cognitive value between the experimental class and the control class has a homogeneous variance.

\subsection{Hypothesis Testing}

In this study, testing the effectiveness and hypothesis used a test. Testing the hypothesis with t-test was utilized to test the effectiveness of game-based learning. The criterion used in taking the hypothesis is $\alpha=0,05$. $\mathrm{H}_{\mathrm{o}}$ is rejected if the probability significance (sig) $<\alpha$ $(0.050)$ and if the probability significance level (sig ) is $>$ $\alpha(0.050)$ then $\mathrm{H}_{\mathrm{o}}$ is accepted. The complete results of the test of effectiveness as well as hypothesis in this study are as follows.

Table 5. t-test Pretest of Experimental and Control Class

\begin{tabular}{lll}
\hline \multirow{3}{*}{ Score } & Class & Mean \\
& Control & 56,00 \\
& Experiment & 55,91 \\
\hline
\end{tabular}

Based on Table 5, it can be seen that the mean or average value of the pretest of the control class is 56 and the experimental class is 55.91. This result indicates that the value of the control class learning outcomes is higher than the experimental class. However, to prove whether there is a significant difference between control class learning outcomes and the experimental class is presented in the table below.

Table 6. Test t-test (Independent samples test) pretest Control and Experimental Class

$\begin{array}{lll} & \text { T count } & \text { Significant } \\ \text { Score } & .062 & .951\end{array}$

Based on Table 6 , it can be seen that the significance value of t-test is 0.951 . The value of significance is higher than 0.05 which means that $\mathrm{H}_{\mathrm{o}}$ is accepted. In addition, the value of $t_{\text {count }}$ is equal to $0,062<t_{\text {table }}$ which is equal to 1,669 . This result shows no significant difference for the mean of student learning outcomes between experimental and control class.

Table 7. Posttest Mean Value of Experimental and Control Class

\begin{tabular}{lll}
\hline \multirow{3}{*}{ Score } & Class & Mean \\
& Control & 64,44 \\
& Experiment & 71,66 \\
\hline
\end{tabular}

Based on table 7, it can be seen that the posttest mean or average value of the experimental class is 71.66 and the control class is 64.44 . It describes that the value of 
the students' experimental class learning outcomes is higher than control class. However, to prove whether there is a significant difference between the experimental class learning results and the control classes is presented in the table below.

Table 8. t-test (Independent samples test) Posttest Experimental and Control Class

$\begin{array}{lll} & \text { T count } & \text { Significant } \\ \text { Score } & 4.294 & .000\end{array}$

Based on table 8 , it can be seen that the significance value of t-test is 0.000 . The value of significance is less than 0.05 which means that $\mathrm{H}_{1}$ is accepted. Furthermore, the value of $\mathrm{t}_{\text {count }}$ is $4.294>$ table that is equal to 1.669 . It shows that there is a significant difference mean of student learning outcomes between experimental and control class. This also proves that students' learning outcomes of experimental class is better than the control class.

The results of this research data that has been described above has a positive correlation with previous theories and / or results of previous research related to the use of media for improving students' achievement. Multimedia products used can be concluded effective in supporting and facilitating students in academic achievement in cognitive, affective and psychomotor domains. Learning with multimedia that combines audio and visual in this specific game is able to stimulate the activity, interest as well as attention of students on certain subject matter in a learning activity. In line with statement from Sri Pudjiastuti (1999: 2) that media is anything that can deliver the message from the sender to the receiver of the message so that it can stimulate the thoughts, feelings, attention, and interests of students in learning process. Followed and supported by Arsyad (2011: 26) that learning media can clarify the presentation of messages and information so that it will facilitate and improve the process and learning outcomes. The same opinion that supports that statement comes from Rudi et al (2009: 127) which explains that multimedia has some characteristics that are generally able to provide a solid learning tool for students such as self instructional, self contained, stand alone, and user friendly (easy to be operated). Additionally, this theory is appropriate and reinforced by Vaughan (2008: 6) which suggests that the use of multimedia is able to provide changes in student attitudes toward learning activities from passive learner into active learner with learning by doing (emphasize more on experience). The role of the teacher is also more likely to be a guide or facilitator of learning and to make students as main characters especially in student-centered activities.

Several previous studies have also supported the results of research presented above. Those are the results of the study by Chen et al (2015) on The Comparison of Solitary and Collaborative Modes of Game-Based Learning on Students' Science Learning and Motivation shows that games both individual and in groups do not show any difference in achievement of learning outcomes. This proves that games either independent or together are able to provide significant improvements from pretest to posttest. Hereafter, the result of the research describes that experiencing games in learning can improve students' enthusiasm in overall learning process. Last but not least, the results also show that games can encourage implicit exploration of science.

\section{Conclusion}

Learning process tends to focus more on lectures or teacher-centered. Supporting facilities only in the form of teaching materials such as books obtained from the school as a handbook with materials that seem concise and only cover the outline on each subject. With only use limited media images at times, so that students are less interested. Students require additional media or media support for helping them in learning and understanding the subject matter that teachers deliver in schools. Teachers have a big responsibility as the sources of information for students. On the other hand, schools have adopted and implemented curriculum 2013 which focuses more on a scientific approach and the learning process is based more on students or commonly referred to as student-centered. The application of multimedia game-based learning as a learning media is positively correlated to students' achievement and their learning attitudes. This can be seen from the improvement of student achievement at the time of pretest and posttest as well as their higher motivation to understand the lesson.

\section{References}

1. Arsyad, Azhar. Media Pembelajaran. Jakarta: PT Raja Grafindo Persada (2011)

2. Chen, C.-H., Wang, K.-C., \& Lin, Y.-H, The Comparison of Solitary and Collaborative Modes of Game-based Learning on Students' Science Learning and Motivation. Educational Technology \& Society, 18 (2), 237-248 (2015)

3. Hacbarth, S, The educational technology handbook. New Jersey: Educational Technology Publications Inc (1996)

4. Harmer, Jeremy. How To Teach Grammar. London. Longman (2006)

5. Heinich, Molenda, Russell, and Smaldino. . Instructional Media and Technologies for Learning. Prentice-Hall, Inc. New Jersey: Upper Saddle River. (2007)

6. Miarso, Yusuf Hadi. (2005). Menyemai Benih Teknologi Pendidikan.Jakarta: Kencana Prenada Media Group.

7. Munir. (2008). Multimedia Konsep dan Aplikasi dalam Pendidikan. Bandung: Alfabeta.

8. Phillips, R. (1997). The developer's Handbook to Interactive Multimedia: A Practical Guide for Educational Applications. London: Kogan Page.

9. Raiser, R.A \& Dempsey, J.V. (2007). Trends and Issues in Instructional Design and Technology. 
Secon Edition. New Jersey: Pearson Merril Prentice Hall.

10. Richards, J.C. (2008). Methodology in Language Teaching. An Anthology of Current Practice. New York: Cambridge University Press.

11. Roblyer, M.D. (2003). Integrating Educational Technology into Teaching ( $3^{\text {rd }}$ ed) New Jersey. Merril Prentice Hall.

12. Rudi Susilana \& Cepi Riyana. (2009). Media Pembelajaran. Bandung: CV Wacana Prima..

13. Simonson \& Thomson. (1994). Instructional Technology: The Definition and Domains of the Field. Washington DC: AECT.

14. Sri Poedjiastoeti. (1999). Media Pembelajaran. Surabaya: Unipres Unesa.

15. Sukardjo dan Lis Permana Sari. (2009). Metodologi Penelitian Pendidikan Kimia.

16. Yogyakarta: FMIPA UNY.

17. Supartono Widyosiswoyo. (1996). Ilmu Budaya Dasar. Jakarta: Ghalia Indonesia.

18. Sutrisno. (2005). Revolusi Pendidikan di Indonesia. Yogyakarta: Ar Ruzz.

19. Suyanto, Kasihani K.E. (2007). English for Young Learners. Jakarta: Bumi Aksara

20. Tay Vaughan. (2008). Multimedia: Making It Work. New York: Mc Graw Hill.

21. Thornburry. S. (2002). How To Teach Grammar. Harlow, Essex: Pearson Education Limited

22. Ur, Penny. (2009). A Course in Language Teaching Practice and Theory. Cambridge University Press.

23. Chen, C.-H., Wang, K.-C., \& Lin, Y.-H, The Comparison of Solitary and Collaborative Modes of Game -based Learning on Students' Science Learning and Motivation. Educational Technology \& Society, 18 (2), 237- 248 (2015).

24. Wright. A, Betteridge. D, and Buckby. M. Games For Language Learning. Third Edition. Cambridge University Press (2006)

25. ProActive: Fostering teachers' creativity through Game-Based Learning (2009)

26. Holl, B.G. Orr, Eur. Phys. J. E 14, 7 (2004)

27. M. Ben Rabha, M.F. Boujmil, M. Saadoun, B. Bessaïs, Eur. Phys. J. Appl. Phys. (to be published)

28. Luigi T. De Luca, Propulsion physics (EDP Sciences, Les Ulis, 2009)

29. F. De Lillo, F. Cecconi, G. Lacorata, A. Vulpiani, EPL, 84 (2008) 